\title{
Integrated E-Commerce Ecosystem in China and Indonesia's Giant Market
}

\author{
Karina Rima Melati ${ }^{1}$, Nur Komala Dewi S.P \\ ${ }^{1}$ Department of Advertising, Sekolah Tinggi Ilmu Komunikasi (STIKOM) Yogyakarta, Indonesia \\ ${ }^{2}$ Department of Advertising, Sekolah Tinggi Ilmu Komunikasi (STIKOM) Yogyakarta, Indonesia \\ Corresponding Author's Email : karinarimamelati@gmail.com
}

\begin{abstract}
The growth of Indonesia's digital economy is expected to be the fastest in the Southeast Asia in 2025 with a number reaching around US\$133 billion. The e-commerce figure in particular, is projected to flourish from US\$ 21 billion in 2019 to US\$ 82 billion in 2025 respectively or increasing by $290,5 \%$. The fascinating progress is due to Indonesia's enormous internet market that penetrates 150 million people or 56\% over 268 million Indonesian population. The rapid improvement also happens in China; with over 1,4 billion populace this state leads with more than $40 \%$ of the world's e-commerce transactions or about US\$ 723 billion in 2019 whereas it is expected to increase at US\$1,095 billion in 2023. This advancement is caused by a strong infrastructure especially by China's world leader marketplace companies that generate integrated e-commerce ecosystem. This research aims to examine the integration of e-commerce ecosystem that occurs in China and Indonesia. With qualitative methods, this research audited and done comparison study of the ecosystem pattern that holds in two biggest e-commerce platforms; Alibaba Group in China and Tokopedia in Indonesia. By analysing a dynamic structure system composed of correlated organizations this study looks at the development of e-commerce ecosystems in Alibaba and Tokopedia. At the end, local culture and behaviour become the most influential factors in shaping the integration of ecosystem which then drive the development of digital economy.
\end{abstract}

Keywords: e-commerce, integrated ecosystem, marketplace platform, digital economy

\section{INTRODUCTION}

The 4.0 industrial revolution puts forward the proficiency of internet technology that has produced artificial intelligence, big data, and sophisticated digital manufacturing automation. A survey done by WeAreSocial (2019) illustrates Indonesia's enormous internet market has been penetrating 150 million people or $56 \%$ over 268 million Indonesian population as well as being the 4th largest country in the world with internet literate. Moreover, Bloomberg.com (2019) describes by 2025 the growth of Indonesia's digital economy is expected to be the fastest in the Southeast Asia with a number reaching around US\$133 billion. McKinsey\&Company also reports Indonesia's digital technology could raise GDP by $\$ 150$ billion, equivalent to an average 1.2 percentage point of additional growth 
each year and would fulfil nearly $60 \%$ of the increase required to reach target $7 \%$ annual GDP growth. From thus numbers e-commerce is predicted to become the biggest contributor to the digital economy in Indonesia ${ }^{1}$. Google, Temasek, dan Bain's surveys show up until 2019 e-commerce contributes Gross Merchandise Value (GMV) at about US\$ 21 billion whereas it is expected to grow in 2025 at US\$ 82 billion or rise 290,5\% (Jayani, 2019). The numbers are half of total ecommerce value in whole Southeast Asia in 2025 which are predicted to be worth of US\$ 153 billion (Widowati, 2019).

In addition to Indonesia, China also benefits from the large number of markets or population. With the largest population in the world or around 1.4 billion population, the digital economic growth in China is quite enormous. According to a report released by the Cyberspace Administration of China (Xinhua, 2019) in 2018 the digital economy value reached 31.3 trillion yuan (4.6 trillion U.S. dollars), accounting for 34.8 percent of the country's total GDP. Thus number is influenced by ecosystem growth from China's three global leading digital platforms namely Baidu, Alibaba dan Tencent. (She, Hong, 2019: 33). China also becomes the world's largest e-commerce market, accounting for more than 40 percent of the value of worldwide e-commerce transactions (Woetzel et al. 2017). In 2018, the ecommerce transaction volume reached 31,63 trillion-yuan dan have become the country's new driver of development (Biao, 2019).

The magnitude numbers achieved by Indonesia and China's e-commerce sector cannot be separated from its ecosystem development. E-commerce ecosystem is an integrated organization that supports the business units of an ecommerce company. Technology, social and implementation along with cultural and user's behaviour become important elements in the development of ecommerce ecosystem. The valuation amount of the e-commerce platform will grow in line with the development of its ecosystem.

Blessed with abundant market China and Indonesia also share two large ecommerce platforms company that dominate in the market; Alibaba Group in China and Tokopedia in Indonesia. This research aims to formulate: firstly, how do Alibaba Group and Tokopedia develop their ecosystem? Secondly, what affects the formation and expansion of ecosystem on each platform? Thirdly, how can the integration have carried out by each platform win business competition?

\section{LITERATURE REVIEW OR RESEARCH BACKGROUND}

\section{E-Commerce}

E-commerce is not just a matter of making business using website or browsing on the internet. It covers all digitally enabled commercial transactions, include all those mediated by digital technology, for the most part, transactions that occur over the internet, the web, and/or via mobile devices. Commercial transactions involve the exchange of value (e.g., money) across organizational or

\footnotetext{
${ }^{1}$ In addition to e-commerce, other digital economic contributors in Indonesia come from the online travel sector, online media and online transportation (known as car hailing)
} 
individual boundaries in return for products or services (Laundon and Traver, 2016: 51-52).

E-commerce has revolutionized and changed traditional commerce and razed the boundaries of space and time. The changes in merchant patterns through diversification of logistics solution that many people consider e-commerce revolution is equivalent to the first industrial revolution back in late $19^{\text {th }}$ century. The most significant value of e-commerce is the ability to expeditiously reach many users and with effective cost regardless a broad geographical location. This greatly helps small and micro businesses to expand their market without facing enormous cost of money and organizational resources. (Pradana, 2015: 172)

\section{1.a. The History of E-Commerce}

Traced from its history, the form of today's e-commerce has shaped from three periods, as stated Kenneth (2016: 67-72) started with invention, negotiation and reinvention period. The invention period started from 1995 where it was a period of explosive growth and extraordinary innovation with the widespread use of the Web to advertise products. E-commerce meant selling retail goods, usually quite simple goods, on the Internet. The rapid growth in e-commerce was fueled by over $\$ 125$ billion in U.S. venture capital. This period of e-commerce came to a close in 2000 when stock market valuations plunged, with thousands of companies disappearing (the "dot-com crash"). Thus, the early years of e-commerce were driven largely by visions of profiting from new technology, with the emphasis on quickly achieving very high market visibility.

The development of e-commerce met new challenge between 2001-2006 where in this period many critics doubting its long-term prospects. However, e-commerce changed to include not just retail products but also more complex services such as travel, financial services, and internet marketing. The reinvention of internet begins in 2007 when the mobile phone was introduced and rapid growth of web 2.0 widespread adoption of consumer mobile devices such as smartphones and tablet computers, the expansion of e-commerce to include local goods and services, and the emergence of an on-demand service economy enabled by millions of apps or applications on mobile devices and cloud computing. This period marked the technological and business phenomenon. At the same time, marketing and advertisements could be personalized to fit the needs of customer. Information asymmetry would be greatly reduced where prices and even costs would be increasingly transparent to the consumer. Manufacturers and content originators would develop direct market relationships with their customers

\section{1.b. E-commerce technology}

The development of e-commerce is possible because the involvement of technology that utilized its self to be more sophisticated. Technology plays important rules to shape the characteristic of e-commerce started from internet, Internet of Things (IoT), cloud computing, big data until Artificial Intelligent 
(AI). The use of technology also suggest many new possibilities for marketing and selling to have unique features such as: ubiquity to characterizes ecommerce as a marketplace; reaching the number of user or customers globally; technical standards for conducting e-commerce are universal standards; offering considerably rich information and complex but plentiful, less expensive and higher quality; allows an online merchant to interact with their customers; personalization or customization the customer based on their profile, preferences, and demands; and giving users the power to create and distribute content on a large scale as well as permit user to program their own content consumption (user-generated content and social networks). (Laundon and Traver, 2016: 53-56)

The e-commerce core business comprises commerce, logistic, financial services, data technology, marketing and advertising services, digital media, entertainment, communication platform, etc. The development of technology also has given an effect in improving the creation of features interface and content in the platform in order to produce loyal consumers. The technology platforms and businesses that consist of consumers, merchants, brands, retailers, third-party service providers, strategic alliance partners and other businesses have contributed a digital economy. In the end technology makes it possible to fulfill the needs of 4,479 billion global internet users (Digital Around the World in October reports from Hootsuite and WeAreSocial.com).

\section{1.c. Types of E-commerce}

In the world of e-commerce system applies its forms of collaboration and interaction among fellow actors. It is also called 'businesses model'. The principals generally come from two stakeholders, the company (symbolized 'B' or business) and consumers (symbolized $\mathrm{C}$ or Customer). The consumers in ecommerce cannot be translated as a passive party or buyer, instead they are empowered as sellers and actively involved in e-commerce business rotation. Sandhusen in Perdana (2015: 169) reveals that stakeholders in the form of government (symbolized G or Government) also becomes part of e-commerce stakeholders in a way as a government agency providing ease of service, however Laudon and Travel (2016: 56) subsume business-to-government (B2G) within B2B, viewing government as simply a form of business when it acts as a procurer of goods/or services. We also include the Online to Offline (vice versa) model business (symbolized $\mathrm{O} 2 \mathrm{O}$ ) to beckon the growth of omni channel business or some said the concept of new retail. 
Here are five major types of e-commerce together with the examples:

\begin{tabular}{|c|c|c|c|}
\hline $\begin{array}{l}\text { Businesses } \\
\text { Model }\end{array}$ & Definition & Business models & Examples \\
\hline $\begin{array}{l}\text { Business- } \\
\text { to- } \\
\text { Business } \\
\text { (B2B) }\end{array}$ & $\begin{array}{l}\text { Online } \\
\text { businesses that } \\
\text { focus on } \\
\text { selling to other } \\
\text { businesses, } \\
\text { which can be a } \\
\text { specific } \\
\text { consent to } \\
\text { support their } \\
\text { model } \\
\text { business }\end{array}$ & $\begin{array}{l}\text { Net marketplaces, which } \\
\text { include e-distributors, e- } \\
\text { procurement companies } \\
\text { exchanges and industry } \\
\text { consortia, and private } \\
\text { industrial networks }\end{array}$ & $\begin{array}{l}\text { - Alibaba.com } \\
\text { - Thomasnet.com } \\
\text { - Go2Paper.com } \\
\text { - Tradeindia.com } \\
\text { - Indiamart.com } \\
\text { etc. }\end{array}$ \\
\hline $\begin{array}{l}\text { Business- } \\
\text { to- } \\
\text { Consumer } \\
\text { (B2C) }\end{array}$ & $\begin{array}{l}\text { Online } \\
\text { businesses that } \\
\text { allows } \\
\text { producers to } \\
\text { reach } \\
\text { consumers } \\
\text { directly }\end{array}$ & $\begin{array}{l}\text { Portals } \\
\text { Online retailers } \\
\text { content providers } \\
\text { Transaction brokers } \\
\text { Market creators } \\
\text { Service providers } \\
\text { Community providers. }\end{array}$ & $\begin{array}{l}\text { - TMall.com and } \\
\text { TmallGlobal } \\
\text { (Alibaba Group) } \\
\text { - AliExpress } \\
\text { - Amazon.com } \\
\text { - Lazada.com } \\
\text { (Alibaba Group) } \\
\text { - Zalora } \\
\text { - Bhinneka.com } \\
\text { - MatahariMall } \\
\text { - Berrybenka } \\
\text { - JD.com } \\
\text { - etc. } \\
\end{array}$ \\
\hline $\begin{array}{l}\text { Consumer- } \\
\text { to- } \\
\text { Consumer } \\
\text { (C2C) }\end{array}$ & $\begin{array}{l}\text { Online e- } \\
\text { commerce that } \\
\text { provides a way } \\
\text { for consumers } \\
\text { to sell to each } \\
\text { other }\end{array}$ & $\begin{array}{l}\text { Consumer prepares the } \\
\text { product and place it on } \\
\text { marketplace platform. } \\
\text { The platform then } \\
\text { provides catalog, search } \\
\text { engine, and transaction } \\
\text { clearing capabilities so } \\
\text { that products can be } \\
\text { easily displayed, } \\
\text { discovered, and paid for. }\end{array}$ & $\begin{array}{l}\text { - Tokopedia } \\
\text { - Taobao(Alibaba } \\
\text { group) } \\
\text { - Bukalapak } \\
\text { - Berniaga } \\
\text { - eBay } \\
\text { - Etsy } \\
\text { - AirBnB } \\
\text { - Gojek } \\
\text { - Grab } \\
\text { - Uber } \\
\text { - OLX } \\
\text { - JD.id } \\
\text { - Craigslist } \\
\text { - etc. }\end{array}$ \\
\hline
\end{tabular}




\begin{tabular}{|c|c|c|c|}
\hline $\begin{array}{l}\text { Consumer- } \\
\text { to- } \\
\text { Business } \\
(\mathrm{C} 2 \mathrm{~B})\end{array}$ & $\begin{array}{l}\text { Online e- } \\
\text { commers when } \\
\text { consumers sell } \\
\text { their product, } \\
\text { most of all } \\
\text { their services, } \\
\text { for the } \\
\text { company. This } \\
\text { type especially } \\
\text { works for } \\
\text { photographer } \\
\text { or graphic } \\
\text { design } \\
\text { customizing a } \\
\text { design, logo, } \\
\text { etc. }\end{array}$ & $\begin{array}{l}\text { Using personal portal or } \\
\text { platform to show } \\
\text { customer's work. }\end{array}$ & $\begin{array}{l}\text { - Istockphoto.com } \\
\text { - sribulancer } \\
\text { - 99designs.com } \\
\text { - shutterstock.com } \\
\text { - etc. }\end{array}$ \\
\hline $\begin{array}{l}\text { Online-to- } \\
\text { Offline or } \\
\text { Offline to } \\
\text { Online } \\
(020)\end{array}$ & $\begin{array}{l}\text { A complete } \\
\text { digitalization } \\
\text { involvement } \\
\text { for both online } \\
\text { and offline } \\
\text { stores }\end{array}$ & $\begin{array}{l}\text { Installed artificial } \\
\text { intelligent technology in } \\
\text { stores where consumers } \\
\text { can experience } \\
\text { unexpected and creative } \\
\text { way of shopping } \\
\text { Provide mobile phone's } \\
\text { apps to engage and } \\
\text { customized customer's } \\
\text { needs }\end{array}$ & $\begin{array}{l}\text { - Mitra (Tokopedia) } \\
\text { - Hema Freshippo } \\
\text { Supermarket } \\
\text { (Alibaba Group) } \\
\text { - Auto Vending } \\
\text { Machine } \\
\text { - Ling Shou Tong, } \\
\text { - AmazonGo } \\
\text { - “Alibaba } \\
\text { Intelligence" with } \\
\text { virtual shelves, } \\
\text { magic mirror in } \\
\text { malls } \\
\text { - Etc. }\end{array}$ \\
\hline
\end{tabular}

Table 1. five major types of e-commerce

In the context $\mathrm{C} 2 \mathrm{C}$ (and views of $\mathrm{B} 2 \mathrm{C}$ ) e-commerce in addition for being a form of empowering and democratizing trade by using technology and platforms, also expands the business model in a wider scale. For example, in the form of social e-commerce, it utilizes social media such as Facebook, Instagram, Twitter, Snapchat, Tiktok as well as room-chats like WhatsApp and WeChat to do the business.

Eventually e-commerce offers services and different resources and collaborations to create sharing economy ${ }^{2}$. Collaborations or what Kotler, Kartajaya and Setiawan (2017: 50) call co-creation is new product development strategy involving customers early in the ideation stage to customize and

2 Other terms such as "collaborative commerce," "peer to peer consumption," "mesh economy," and "we-commerce." See Kenneth C. Laudon and Carol Traver (2016:776) 
personalize products and services. Co-creation generates on-demand services connect providers ("sellers") who wish to spare their resources such as cars or motorcycle (known as ride-hailing), rooms, personal or labor skill (such as cleaning, massages, washing, etc), order and delivering food, ticketing, customized traveling, etc. This new market and superior value propositions would create disruption which change the wave of conventional business and have been changing human civilization (Kasali: 2018)

\section{E-Commerce Ecosystem}

Platform provides the infrastructure to develop applications and special support until multiple workflows. The e-commerce platform originally focus on primary functions which are displaying the product, making an order, payment system, and making sure products that have been ordered shipped on the right address. However, the above-mentioned functions are not sufficient. The growing audience means that the platform should utilize it in order to be more creative and engage with them by building new-type of economic connection and relations based on data and information network with the principle of business ecosystem.

The ecosystem explains multipurpose device that can handle an-ever larger channel services in one group of business. E-commerce ecosystem is internally and externally diverse that interact through a series of activities that can be important factors for the business evolution as a whole. It is also be defined as a dynamic structure system composed of correlated organization (Li, Liu and Xie, 2009: 457). The e-commerce ecosystem is composed of series of enterprises and organizations closely related beyond the geographical boundaries, takes Internet for a competition and communication platform, completes complementary and resource sharing through virtual, alliances and other forms, exchanges funding, capital and information relying on their core competencies and strengths in order to achieve added value. (Tian, Zhan and Guam, 2014: 45). The complexity of e-commerce ecosystem includes public policy environment of the country (Hanna, 2016: 6)

There are many institutions includes in the e-commerce ecosystem that includes the core e-commerce companies, such as: suppliers, customers, payment institutions or payment gateway, financial institutions, logistics companies, marketing and advertising institution, recommendation agents, certification bodies, insurance companies, telecommunications service providers, software providers, internet technology providers, government departments, industry associations, technology outsourcing business, e-commerce consulting service providers, omni channel or new retail, etc. The organizations can be enterprises, colleges, institutions, social public institutions and other organizations related to the system, which are closely interwoven and integrated.

In this paper we will explore the complexity of the e-commerce ecosystem of the two large marketplace companies, Alibaba Group and Tokopedia. Alibaba Group, in their $20^{\text {th }}$ of establishment have been generating revolutionary ecosystems and involving myriad of platforms, from B2B, B2C and C2C with cross-border trading areas. Meanwhile, Tokopedia, despite only a decade after its 
development, is fast enough to make Tokopedia platform superior as the top marketplace player in Indonesia.

The urgency of this research is to formulate the various elements of the ecosystem that work in e-commerce companies to then see how they build, expand and connect the networks within as to support one another. Another important reason is by comparing two marketplaces, Alibaba and Tokopedia, we will examine the adaptation that have been done by those who companies as to evaluate core business, expansion and various correlations in their e-commerce ecosystem. In turn, this research is expected to contribute to the lack of literature on the ecommerce ecosystem in Indonesia.

\section{METHODOLOGY}

While the development of e-commerce is so rapid and sophisticated, the methodological framework of research about the ecosystem mechanism and its system is lacking. The aim of this paper is to establish a new theoretical and methodological model based on the work of e-commerce ecosystem. The description model considers steps to answer the research questions using three framework of e-commerce ecosystem from the study done by Xinjian Li, Qihua Liu and Jinjing Xie, (2009) which then become the variable to be analyzed:

1. Core layer: the core organism or most basic components that include buyer, vender, core products and services and trade platform.

2. Expansion layer: supporting core layer and playing important roles such as supplier, customer, related financial institution, logistic company, insurance agent, software service provider, advertising service provider, and so on, supporting the core

3. Correlation layer: supporting the sound operation of information flow, business flow and logistics, such as government departments, industrial organizations, standard institutions, education and scientific research institutions and other organizations related to network retail.

This research examines its population which includes two companies in two country using comparative description method with a qualitative approach. Comparative research study is comparing the existence of one or more variables in two or more different samples, at different times. Moreover, the comparation of two companies in two different regions also include to compare policy formulation, development and implementation using 'international comparative research method' by Linda Hantrais (2009). The method helps undertaking comparative studies in international setting such us define characteristic of across nations, societies and cultures. The selection of object of inquiry, units and levels of analysis in relation to socioeconomic and political phenomena in relation to their institutional and sociocultural settings. That is include policy interface in each country. Peter Grootings in Linda Hantrais (2009: 3) advocated international comparative research as the most effective approach on the grounds that is systematically analyses the relationship between the social phenomenon under study and relevant characteristic of the country. 
In using a comparative-qualitative method the research also conducts an indepth evaluation of the units differences in the ecosystem between Alibaba and Tokopedia by field observation together with audio-video observation, literature studies, and conduct online interview with some authorities. Although there is a gap between two companies in terms of coverage amount and valuation both companies share values of traditions which is based on their customer. The customer-centric method shapes the ecosystem as Kim, Sohn and Choi (2011) describes the cultural context shapes the use of communication technology and patterns the social networking. Media avidity is conceivably different in every country which conforms the cultural characteristics of each country (Perdana, 2016:170)

\section{RESULTS AND DISCUSSION}

The analyses are divided in three major explanations; first is the situations or Alibaba Group and Tokopedia's history and its development, second ecosystem that have assembled in Alibaba Group and Tokopedia, and third is the comparison among them.

\section{The Situations}

\section{1.a. Alibaba Group}

Alibaba.com as later well-known as Alibaba Group was founded 20 year ago on April $4^{\text {th }} 1999$ by Jack Ma and his 18 co-founders in humble apartment, Hangzhou, China. Alibaba Group is now ranked among the world's top 10 companies in terms of market value. Alibaba believes that internet technology would enable small enterprises to grow more effectively in domestic and global economies. Their mission is to provide the technology infrastructure to help merchants, brand and other businesses to transform the way they market, sell and operate together with improving their efficiencies; as it is their statement "To Make It Easy to Do Business Anywhere". Nonetheless, their vision is to build the future infrastructure of commerce that lasts at least 102 years or live in three periods of century; built in 2009 or during $20^{\text {th }}$ century, now is the $21^{\text {st }}$ century and by the time reaching 102 years will be in 2101 which is in $22^{\text {nd }}$ century.

Started their business by running the marketplace of Alibaba.com (B2B platform) and 1688.com (B2C platform). In the late 1999 Alibaba received \$25 million from Sachs and SoftBank which allowed them to improve the small and medium enterprises (SMEs). In 2002 Taobao.com (C2C platform) was established and challenged eBay.com that started to expand into China market in 2003. Alipay, an online payment platform was launched in 2004 with no transaction fees. In 2005 Yahoo! bought $40 \%$ stake in the company for US\$ 1 billion. At the same time Alibaba launched TaobaoMall, later Tmall.com, a marketplace platform offering large, multinational global brands to an increasingly Chinese middle class. In 2009 as commemorating $10^{\text {th }}$ anniversary, Alibaba established Alibaba Cloud, a largest high-tech computing company in China. The Alibaba Cloud then becomes the foundation of Alibaba ecosystem to support data technology platform. 
The Alibaba group flared up more greatly in 2009 where they held Double Eleven or Single Shopping Festival on Taobao.com. Double Eleven is very famous among Chinese youngsters that has turned to be the largest shopping event in the world and has remained a significant driving force in China's economy. Started from US\$ 7.48 million total Gross Merchandise Volume (GMV) in 2009 then the number exceeded to US $\$ 30.8$ billion GMV in 2018, which was more than twice the size of the USA's shopping festival Black Friday and Cyber Monday combined. The success of Double Eleven has originated from a strong Alibaba Group ecosystem.

As a huge digital technology-based marketplace company logistic, financial and cloud computing are the most essential infrastructures in Alibaba. Logistics are handled by CaiNiao with 231 cross-border warehouses which manage millions of packages to more than 220 countries and more than 2000 regions in China. In 2018 sent 50 billion packages or cover $50 \%$ of total global shipping.

In the payment and financial service Alibaba group is supported the biggest e-pay platform in China, Alipay. Even after it is transformed to become 'Ant Financial' they expand their business outside China which cover 55 markets in four continents (per February 2019) or more than 900 million annual users. However, for cloud computing Alibaba Cloud becomes the backbone of all Alibaba business group that develops cloud technology, big data and Alibaba Intelligent (another name for Artificial Intelligent) as Alibaba. Cloud technology also have enabled Alibaba Group to emerge the market which will in turn contribute long-term growth including to support 1.04 billion orders during Double Eleven Global Shoping Festival 2018.

Alibaba really plays important role in shaping the success of Chinese's digital economy. In the quarter year of 2019 the revenue was US $\$ 13,932$ million, US\$768 million annual GMV, with 755 million active user (June 2019), 666 million mobile active consumer, 443 million active buyer, and generates 100 million packets purchase per day. Taobao platform becomes the fastest growing consumer community and new shopping experience while Tmall leads in consumer engagement and distribution platform for brand in China. The major factor of accomplishment is that $90 \%$ of transaction is done by mobile phone and tablet which then provoke $\mathrm{m}$ commerce or mobile commerce. 800 million out of 1,4 billion Chinese total population are active mobile user. Alibaba Group also invests heavily in reaching customer through cloud computing and virtual reality.

\section{1.b Tokopedia}

Tokopedia is the biggest $e$-commerce marketplace in Indonesia with US\$ 7 billion of total GMV and become one of top ten Southeast Asia unicorns (May, 2019). Established on August $17^{\text {th }} 2009$, coincide with Indonesian Independent's Day, by William Tanuwijaya and Leontinus Alpha Edision with the mission is "Pemerataan Ekonomi secara Digital" or Digital 
Economy Equality with the advancement of technology and huge Indonesia's market.

Tokopedia has been developing C2C (Customer to Customer) platform marketplace that embraces Small and Medium Enterprises (SME) to sell their product online. At the beginning of its establishment, it has cooperated with 509 merchants and 4560 active users. Their vision become the pioneer in digital transformation in Indonesia as well as to empower millions of sellers and consumers to participate in the future of Indonesian economy. Their statement is "Mulai Aja Dulu" or Let's Start First to encourage people to do business through internet.

After one year of establishment Tokopedia managed to reach an accumulated transaction turnover of 1 billion rupiah in early 2010 and an increase of 4659 merchants with 44785 members. Moreover, venture capital companies also stated to come and provide investment to this company. After PT Indonusa Dwitama as Tokopedia's first join venture capital, it was followed by East Ventures (Singapura), CyberAgent Venture, Beenos, Softbank Telecom Corp, Sequoia Capital and Softbank Ventures Korea. Total amount of investment recorded was US\$100 million or 1.4 trillion rupiah and marked Tokopedia as the first unicorn in Indonesia in 2014. The success of encompass fund from venture capital return to come in the following years, including from Alibaba Group that provided US\$1.1 billion in 2017.

Over the past 10 years Tokopedia has grown significantly and has boosted digital economic equality through its ecosystem. In the next decade Tokopedia focus on 'SuperEcosystem' as to bridge for many partners, including logistic dan payment institution. Tokopedia accounts $1 \%$ of Indonesia's total economy with more than 200 million registered products at transparent prices; more than 6.4 million sellers; more than 90 million active monthly users and reach $97 \%$ of districts in Indonesia.

\section{Ecosystem}

\section{2.a. Alibaba Group Ecosystem}

As the company's businesses account for more than half of all ecommerce sales in China and connecting manufactures with buyers from many countries around the world, Alibaba's ecosystem is very complex. The foundation mainly directed to merchants and traders to support their business offering, the convenience, financial services, payment, logistic, data science and analytic service, advertising, machine learning and cloud. All of the unit business are driven by data technology to execute online integration and offline digitization.

There are three pillars of the ecosystem, which are Core Commerce, Media and Entertainment dan Local Service. First, Core Commerce is platforms that have been established not only as marketplace, but also data technology platforms which embodied the vision and mission of the company. As a core of commerce company, Alibaba also up to the challenge 
of saturation offline retail by setting up what it is called "new retail" experience (number 10-13). The platforms are:

1. Alibaba.com (B2B),

2. Taobao.com $(\mathrm{C} 2 \mathrm{C})$,

3. TMall.com (B2C),

4. Lazada (B2C),

5. Jushuasoan.com (sales and marketing platform for flash sales,

6. AliExpress,

7. 1688.com (B2C),

8. cun.taobao.com (rural e-commerce site),

9. TMall Global (B2C cross border marketplace).

10. Hema Freshippo Supermarket, a smartphone-powered experience that can do shop from home or inside the store

11. Auto Vending Machine as a test drive vending machine

12. Ling Shou Tong, a built an application to digitize convenience store

13. Equipped "Alibaba Intelligence" (instead of Artificial Intelligence) with virtual shelves, magic mirror in malls

Second is the Entertainment. The unit is cover digital media and entertainment platforms to engage the digital consumer, as well as to understand customer behaviour, catalyse behaviour in certain direction and to improve service continuously. The platforms are:

1. Youku.com, a Chinese's YouTube version

2. Tudou.com

3. TMall TV

4. Alibaba Music

5. UC Browser

6. Alisport.com

7. Alibaba picture

The third pillar is Service platforms. Service platforms are local services that incorporate technology and data to improve offline world of Chinese consumer by using data. The convenience services are made to fulfil the customer's daily needs like:

1. Tickets, purchasing tickets

2. Fliggy, online travel platform

3. Ele.me, food delivery service platform

4. Kuobei, a life search engine providing living consumption information, restaurant, house renting, and buying, travelling, and more.

5. Hangzhou smart city/ City Brain, Kuala Lumpur (Malaysia) City Brain

6. Aviation brain in Beijing International Airport

Those three units are sustained with business operation system, such as:

1. Education \& Training Platform: Alibaba Business School, Rural Taobao 
2. Logistic infrastructure: CaiNiao

3. Marketing Service and Data Management Platform: Alimama

4. Payment \& financial Services Infrastructure: Alipay and Ant Financial

5. Cloud Computing, Technology \& System Infrastructure: Alibaba Cloud

6. Enterprise Communication \& Collaboration Platform: DingTalk

\section{2.b. Tokopedia Ecosystem}

Tokopedia's ecosystem is marked from four pillars; Marketplace and Digital Product; Fintech and Payment; Logistic and Fulfilment; and New Retail. All is integrated in one platform of Tokopedia.com which then derivate the features that fit with the core commerce. Detail explanation of Tokopedia is described following:

First, "Marketplace dan Produk Digital" or Marketplace and Digital Product is an online marketplace application that consist of Tokopedia.com

1. Seller Tokopedia: feature that facilitates supplier to manage their online businesses with sales statistic review

2. Parentstory: Tokopedia's digital product aids to educate parent about their children's activities online.

3. Bridestory: Tokopedia's bride digital product expedites to relate bride with thousand vendors.

Second, “Tekfin dan Pembayaran" or Fintech and Payment is a Tokopedia's digital financial product that helps consumers with finances matters

1. Tokopedia Payment and Financial Produk:

a. Reksa Dana: where consumers invest

b. Pinjaman Online: online loan.

c. Pinjam Modal: financial loaning for online business person

d. Kartu Kredit: facilitates consumer to online credit card apply

e. Asuransi: online insurance services

2. OVO: online payment method

Third, Logistik dan Fulfillment or Logistic services is an integrated logistic and shipping service with fulfilment system to facilitate smart and convenience warehouse and shipping

1. Toko Cabang: warehouse and shipping

Fourth, New Retail equip and empower traditional retailer with technological means to sell online product and allows them to stock efficient goods based on the most sales.

1. Mitra Tokopedia: kios pulsa and online wholesale supplier.

2. Tokopedia Corner: pick-up parcel place in colleges and universities. 


\section{Comparation}

The comparation description is to analyze Alibaba and Tokopedia's platforms (together with features) based on three variables which are Core Layer, Expansion Layer and Correlation Layer.

\begin{tabular}{|c|c|c|}
\hline Variables & Alibaba Group & Tokopedia \\
\hline $\begin{array}{l}\text { Core layer: the } \\
\text { core organism or } \\
\text { most basic } \\
\text { components that } \\
\text { include buyer, } \\
\text { vender, core } \\
\text { products and } \\
\text { services and trade } \\
\text { platform }\end{array}$ & $\begin{array}{l}\text { - Alibaba.com (B2B), } \\
\text { - Taobao.com (C2C), } \\
\text { - TMall.com (B2C), } \\
\text { - Jushuasoan.com } \\
\text { - Lazada.id } \\
\text { - AliExpress cross border } \\
\text { - } 1688 . c o m(B 2 C), \\
\text { - cun.taobao.com (rural e- } \\
\text { commerce site), } \\
\text { - TMall Global } \\
\text { - Hema Freshippo new retail } \\
\text { supermarket }\end{array}$ & Tokopedia.com \\
\hline $\begin{array}{l}\text { Expansion layer: } \\
\text { supporting core } \\
\text { layer and playing } \\
\text { important roles } \\
\text { such as supplier, } \\
\text { customer, related } \\
\text { financial } \\
\text { institution, } \\
\text { logistic company, } \\
\text { insurance agent, } \\
\text { software service } \\
\text { provider, } \\
\text { advertising } \\
\text { service provider, } \\
\text { and so on, } \\
\text { supporting the } \\
\text { core }\end{array}$ & $\begin{array}{l}\text { - CaiNiao } \\
\text { - Alimama } \\
\text { - Alipay and Ant Financial } \\
\text { - Alibaba Cloud } \\
\text { - DingTalk } \\
\text { - Youku.com } \\
\text { - Tudou.com } \\
\text { - TMall TV } \\
\text { - Alibaba Music } \\
\text { - UC Browser } \\
\text { - Alisport.com } \\
\text { - Alibaba picture } \\
\text { - Tickets } \\
\text { - Fliggy } \\
\text { - Ele.me } \\
\text { - Kuobei }\end{array}$ & $\begin{array}{l}\text { - Seller Tokopedia } \\
\text { - Toko Member } \\
\text {-OVO } \\
\text { - Toko Cabang } \\
\text { - TopAds adveriting } \\
\text {-Parentstory } \\
\text { - Bridestory } \\
\text { - Langsung Laku }\end{array}$ \\
\hline $\begin{array}{l}\text { Correlation } \\
\text { layer: supporting } \\
\text { the sound } \\
\text { operation of } \\
\text { information flow, } \\
\text { business flow and } \\
\text { logistics, such as } \\
\text { government } \\
\text { departments, } \\
\text { industrial } \\
\text { organizations, } \\
\text { standard } \\
\text { institutions, }\end{array}$ & $\begin{array}{l}\text { - Alibaba Business School } \\
\text { - Rural Taobao } \\
\text { - Ling Shou Tong } \\
\text { - Equipped Alibaba Intelligence } \\
\text { with virtual shelves, magic mirror } \\
\text { in malls } \\
\text { - Auto Vending Machine as a test } \\
\text { drive vending machine } \\
\text { - Hangzhou Smart City (cooperate } \\
\text { with Hangzhou Local } \\
\text { Government) and Kuala Lumpur } \\
\text { (Malaysia) City Brain (cooperate } \\
\text { with Malaysia Government) }\end{array}$ & $\begin{array}{l}\text {-Tokopedia Keuangan } \\
\text { - Reksadana (mutual fund) } \\
\text { - Pinjaman online (online } \\
\text { loan) } \\
\text { - Pinjam Modal (financial } \\
\text { loaning) } \\
\text { - Kartu Kredit (credit card) } \\
\text { - Asuransi (insurance) } \\
\text { - Vehicle tax (cooperate } \\
\text { with village businesses } \\
\text { unit entity of West Jave } \\
\text { Local Government) }\end{array}$ \\
\hline
\end{tabular}




\begin{tabular}{|c|c|c|}
\hline $\begin{array}{l}\text { education and } \\
\text { scientific research } \\
\text { institutions and } \\
\text { other } \\
\text { organizations } \\
\text { related to network } \\
\text { retai }\end{array}$ & $\begin{array}{l}\text { - Aviation brain in Beijing } \\
\text { International Airport }\end{array}$ & $\begin{array}{l}\text { - Umrah (cooperate with } \\
\text { Indonesia ministry of } \\
\text { Communication and } \\
\text { Informatics) } \\
\text { - Tax (cooperate with local } \\
\text { bank institutions) } \\
\text { - Property tax (cooperate } \\
\text { with local bank } \\
\text { institutions) } \\
\text { - Pelayanan Publik } \\
\text { (cooperate with local } \\
\text { bank institutions) } \\
\text { - New Retail } \\
\text { - Tokopedia Corner } \\
\text { - Mitra tokopedia } \\
\text { - Tokopedia Corner } \\
\text { (cooperate with Ministry of } \\
\text { Village, Development of } \\
\text { Disadvantaged Region and } \\
\text { Transmigration) } \\
\text { - Tokopedia Center } \\
\text { (cooperate with Ministry of } \\
\text { Village, Development of } \\
\text { Disadvantaged Region and } \\
\text { Transmigration) } \\
\text { - Tokopedia Scholarship } \\
\text { (cooperate with Ministry of } \\
\text { Village, Development of } \\
\text { Disadvantaged Region and } \\
\text { Transmigration) } \\
\text { - Jakarta Smart City } \\
\text {-Tiket Kereta Api } \\
\text { - Tiket Pesawat } \\
\text { - Hotel } \\
\text { - Deals } \\
\text { - Tokopedia Official Store }\end{array}$ \\
\hline
\end{tabular}

Table 2. Comparation of three framework of e-commerce ecosystem in Alibaba Group and Tokopedia

In core layer, the main organism from both companies boils down to marketplace platform. Alibaba Group has developed various platforms with various business model; B2B, B2C, C2C and $\mathrm{O} 2 \mathrm{O}$ through new retail. This development is carried out to cover the enlargement of business both domestic and abroad. The large population or market has strengthened Alibaba in developing businesses units and its ecosystem. The opportunity to sell product abroad because China is among the largest exporting countries in the world with a value worth of US \$218.2 billions (September 2019 by TradingEconomy.com). The cross-border business 
platform is eventually not only done by big companies but also opens up opportunities for the micro industry based on types of business unit model.

Tokopedia on the other hand has developed the main and only $\mathrm{C} 2 \mathrm{C}$ platform. The $\mathrm{C} 2 \mathrm{C}$ marketplace is the most superior in Indonesia at the same time experience intense competition. Tokopedia faces contention from $\mathrm{C} 2 \mathrm{C}$ marketplace such as Bukalapak.com, Blibli.com, Bhinneka.com; including Shopee, Lazada (part of Alibaba Group), to JD.ID

The development of this type of business unit is certainly not the matter of making platforms, but the approval networks from products or suppliers, markets or consumers, business operations and supported by payment institution, logistics and big data infrastructure. Thus, the competition with other marketplace is not only a matter of strong infrastructures but also integration with one another.

Expansion layer is the foundation of core layer where the platform institutions are made to support and play important roles such as logistic, payment and financial service, cloud computing and even advertising and marketing services. Alibaba equips all of that even engaging their user with entertainments platforms and services platforms for Chinese customer. Alibaba Group integrates the services for local so that they can use them from early morning when they wake up until late before they sleep. All infrastructure in the expansion layer also plays a very important role in the world's biggest shopping festival Double Eleven.

Meanwhile Tokopedia still implicates the second party to manage their logistics (branch shop) and OVO payment institution, which belongs to the Lippo Group. To engage with sellers, members and customers, the platform are providing with features of entertainment, coupon and promotion. They also acquired marketplaces for families such as bridgestory and parentstory in order to understand their customers' pattern. Those engagement would be translated into data and become the indicator to hold even such Tokopedia Ramadhan Extra. The event is to actualize the shopping tradition during Ramadhan. Tokopedia graps the opportunity to make a shopping even for the largest muslim population in the world. In 2019 Ramadhan Extra set a transaction record up to Rp 18,5 trillion rupiah or equivalent to US\$ 1.3 million and became the biggest online shopping event ever in Indonesia.

In the correlation layer Tokopedia has built ecosystem with complex platforms and features. This shows that what Tokopedia is trying to build and strengthen communities with a network of cooperation system. The features that have installed in the platform is to facilitates services from various parties, both private and government authorities, including more than hundreds payment services and funding institution such as electricity, taxes, insurance, loan

Alibaba Group instead correlated with parties to support their core dan expansion layer. For example cooperating with villages that have supplied in Taobao through Rural Taobao and installed artificial intelligent in stores and malls as to develop new retail. In this correlation layer Alibaba evolving e-commerce education and training courses for public and private offices. 


\section{CONCLUSION}

The development of e-commerce ecosystem in both Alibaba and Tokopedia marketplace companies is very much felt and influenced by their vision and mission. Through the "To Make It Easy to Do Business Anywhere" statement, the various infrastructures in the Alibaba group ecosystem have been able to facilitate and enable companies, sellers and consumers to make their business comprehensively with global reach. Moreover, with sophisticated technology, Alibaba's founder Jack Ma said in Forbes Global CEO Conference 2019 that "In the future Alibaba is no more e-commerce platform but a data technology platform". While the Tokopedia's founder William Tanujaya explains jargon "Mulai Aja Dulu" or Let's Start First in Tech in Asia Conference 2019 gives an explanation "To invite businesses, sellers and consumers to start and democratize commerce through technology in Tokopedia's platform where anyone can discover everything". Thus, the development of the platform intends to bridge the various needs of Indonesian consumers by Tokopedia through correlation with various related parties.

Ecosystem development is also very much influenced by the number of markets they want to embrace or customer centric. They facilitate different consumer needs according to their culture and behaviour through platforms and features, which then become the ecosystem. The actions of Alibaba Group in running their business certainly inspire many other marketplaces, but of course they still have to adapt their customer culture. Taobao and Tmall's Double Eleven shopping festival inspire many marketplaces to do the same thing, for example through date matching as shopping time. But Tokopedia does not follow this and is more contextual in the traditions in Indonesia which makes Ramadhan Extra the largest national shopping festival day.

Finally, the integration of various infrastructure in the ecosystem is done to 'bind' the users faithfully to both Alibaba Group's platforms and Tokopedia. In the midst of intense competition in the e-commerce platform, Alibaba gains a pretty tight trading rival with the two e-commerce giants Tencent and JD so that the integration of its entire ecosystem network could boost sales and win the competition to generate revenue up to US \$13,932 million, US \$ 768 million annual GMV, with 755 million active users (June 2019), 654 million active consumers, 443 million active buyers, and generates 70 million packet purchases per day. While Tokopedia's built ecosystem network makes it easy for the Indonesian market to meet other needs besides shopping, payment, purchasing, entertainment and information contained in its features to outperform other Indonesian marketplace players where in qualification when in 2019 more than 200 million registered products; more than 6.4 million sellers; more than 90 million active monthly users, reaching $97 \%$ of Indonesia's sub-districts and contributing $1 \%$ to the total Indonesian economy. 


\section{ACKNOWLEDGMENT}

The author would like to thank to Indonesia Ministry of Education Ministry of Research, Technology and Higher Education of the Republic of Indonesia who had gave scholarship to participate in the Retooling Program entitled Lead In the Digital Innovative Era, in Taobao University, Alibaba Business School, Hangzhou, China, July $29^{\text {th }}-$ August $23^{\text {rd }} 2019$.

\section{BIODATA}

Karina Rima Melati, S.Sn., M.Hum is a lecturer of Advertising Dept on Sekolah Tinggi Ilmu Komunikasi (STIKOM) Yogyakarta, Indonesia. She has a research interest in digital media and cultural studies.

Nur Komala Dewi S.P is a student of Advertising Dept on Sekolah Tinggi Ilmu Komunikasi (STIKOM) Yogyakarta, Indonesia

\section{REFERENCES}

\section{Books}

Kasali, Rhenald. 2018. Disruption: Tak Ada yang Tak Bisa Diubah Sebelum Dihadapi, Motivasi Saja Tidak Cukup. Jakarta: PT Gramedia Pustaka Utama Kotler, Philip, Kartajaya, Hermawan., Setiawan, Iwan. 2017. Marketing 4.0 Moving from Traditional to Digital. New Jersey: John Wiley \& Sons

Laudon, Kenneth C and Travel, Carol Guercio. 2016. E-Commerce. Business. Technology. Society. Global Edition 12 E. Essex: Pearson Education Limited.

Hantrais, Linda. 2009. International Comparative Research: Theory, Methods and Practice. New York: Palgrave MacMillan

\section{Article or Chapter within a Book}

Shen, Hong. 2019. China's Tech Giants: Baidu, Alibaba, Tencent. Panorama Insights into Asian and European Affairs. Singapore: Konrad-AdenauerStiftung, Singapore

\section{Article in a Scientific Journal}

Hanna, Nagy K., 2016. E-Commerce as A Techno-managerial Innovation Ecosystem: Policy Implications. Journal of Innovation Management. JIM 4, 1(2016) 4-6

Li, Xinjian., Liu, Qihua., Xie, Jingjing. 2009. Study on the Diversity of E-Commerce Ecosystem and an Example. Second International Workshop on Computer Science and Engineering. DOI 10.1109/WCSE.2009.852. 457-461

Pradana, Mahir. 2015. Klasifikasi Bisnis E-Commerce di Indonesia. Modus Vol 27 (2). 163-174 
Tian, Zhihong., Zhan, Zhenji., Guan, Xiaolan. 2014. New Structural Analysis Model of E-Commerce Ecosystem Network. International Journal of Hybrid Information Technology Vol. 7. No. 1. 43-56

\section{Article or Chapter within a Book}

Das, Tamhane, Vatterott, Wibowo, Wintels. (2018, August). Making Digital Indonesia A Reality. The Digital Archipelago: How Online Commerce is Driving Indonesia's Economic Development. Jakarta: McKinsey \& Company

\section{Electronic/Internet Source}

Biao, Wang. 2019, May $6^{\text {th. }}$ Chinas's Digital Economy Reaches 31.3 Trillion Yuan in 2018. http://www.xinhuanet.com/english/2019-05/06/c_138038007.htm. September $23^{\text {rd }} 2019$

Jayani, Dwi Hadya. 2019 October 10 ${ }^{\text {th }}$. Inilah Potensi Ekonomi Digital Indonesia 2015-2025. https://databoks.katadata.co.id/datapublish/2019/10/04/inilahpotensi-ekonomi-digital-indonesia-2015-2025. October $11^{\text {th }} 2019$

Kemp, Simon. 2019, October 23 ${ }^{\text {rd }}$. The Global State of Digital in October 2019. https://wearesocial.com/blog/2019/10/the-global-state-of-digital-in-october2019. October $26^{\text {th }} 2019$

Kemp, Simon. 2019, January 30 ${ }^{\text {rd }}$. Digital 2019: Global Internet Use Accelerates. https://wearesocial.com/blog/2019/01/digital-2019-global-internet-useaccelerates. September $2^{\text {nd }} 2019$

Lee, Yoolim. 2019, October $3^{\text {rd }}$. Southeast Asia's Internet Economy to Top $\$ 100$ Billion This Year. https://www.bloomberg.com/news/articles/2019-1003/southeast-asia-s-internet-economy-to-top-100-billion-this-year. October $4^{\text {th }} 2019$

Widowati, Hari. 2019 October $3^{\text {rd }}$. Indonesia Kontributor Terbesar Ekonomi Digital di Asia Tenggara. https://databoks.katadata.co.id/datapublish/2019/10/03/indonesiakontributor-terbesar-ekonomi-digital-di-asean. October $11^{\text {th }} 2019$

Woetzel, Seong, Wang, Manyika, Chui and Wong. August 2017. China's Digital Economy: A Leading Global Force. https://www.mckinsey.com/featuredinsights/china/chinas-digital-economy-a-leading-global-force. September $2^{\text {nd }} 2019$ 